\title{
Particulate air pollution and impaired lung function [version
}

\section{1; peer review: 3 approved]}

\author{
Laura Paulin, Nadia Hansel
}

Division of Pulmonary and Critical Care, Johns Hopkins School of Medicine, Baltimore, Maryland, 21224-6801, USA

V1 First published: 22 Feb 2016, 5(F1000 Faculty Rev):201
https://doi.org/10.12688/f1000research.7108.1

Latest published: 22 Feb 2016, 5(F1000 Faculty Rev):201

https://doi.org/10.12688/f1000research.7108.1

\begin{abstract}
Air pollution is a leading cause of morbidity and mortality throughout the world, particularly in individuals with existing lung disease. Of the most common air pollutants, particulate matter (PM) is associated with an increased risk of exacerbations and respiratory symptoms in individuals with existing lung disease, and to a lesser extent, in those without known respiratory issues. The majority of published research has focused on the effects of PM exposures on symptoms and health care utilization. Fewer studies focus on the impact of PM on objective measurements of pulmonary function. This review will focus on the effects of PM exposure on objective measurements of lung function in both healthy individuals and those with existing lung disease.
\end{abstract}

\section{Keywords}

Air pollution, Particulate matter , Lung function , asthma , COPD , lung development

\section{Open Peer Review}

Approval Status

1

2

3

version 1

22 Feb 2016

Faculty Reviews are review articles written by the prestigious Members of Faculty Opinions. The articles are commissioned and peer reviewed before publication to ensure that the final, published version is comprehensive and accessible. The reviewers who approved the final version are listed with their names and affiliations.

1. Alfésio Luís Ferreira Braga, University of Sao Paulo Medical School, Sao Paulo, Brazil Catholic University of Santos, Santos, Brazil

2. Stephan F van Eeden, University of British Columbia, Vancouver, Canada University of British Columbia, Vancouver, Canada

3. Xinbiao Guo, Peking University School of Public Health, Beijing, China

Any comments on the article can be found at the end of the article. 
Corresponding author: Laura Paulin (Ipaulin1@jhmi.edu)

Competing interests: The authors have no competing interests to disclose.

Grant information: LMP is supported by NIH grant K23ES025781, NNH is supported by NIH grants R01ES023500, R01ES018845, R01ES022607, P50MD010431, P01ES018176/ RD83451001, and P50ES015903.

Copyright: ( $) 2016$ Paulin L and Hansel N. This is an open access article distributed under the terms of the Creative Commons Attribution License, which permits unrestricted use, distribution, and reproduction in any medium, provided the original work is properly cited.

How to cite this article: Paulin $L$ and Hansel N. Particulate air pollution and impaired lung function [version 1; peer review: 3 approved] F1000Research 2016, 5(F1000 Faculty Rev):201 https://doi.org/10.12688/f1000research.7108.1

First published: 22 Feb 2016, 5(F1000 Faculty Rev):201 https://doi.org/10.12688/f1000research.7108.1 


\section{Introduction}

Air pollution is associated with millions of premature deaths worldwide $^{1}, 25 \%$ of which are estimated to be respiratory in nature ${ }^{2}$, and is the world's largest environmental health risk ${ }^{3}$. In an attempt to mitigate ambient exposure to air pollution, the Environmental Protection Agency (EPA) currently regulates six criteria air pollutants under the Clean Air Act ${ }^{4}$. Of the regulated pollutants, particulate matter (PM) has been extensively studied and associated with a myriad of adverse health outcomes, including an adverse impact on lung function in both children and adults ${ }^{5-7}$. PM is a complex mixture of liquid droplets and extremely small particles composed of organic and inorganic compounds ${ }^{7}$. PM less than $10 \mu \mathrm{g}$ in aerodynamic diameter, designated by $\mathrm{PM}_{10}$, can penetrate conducting airways; $\mathrm{PM}_{2.5}$ (PM less than $2.5 \mu \mathrm{g}$ in aerodynamic diameter) is composed of fine particles and can penetrate into the gas-exchanging regions of the lung ${ }^{6}$. Sources of ambient PM include construction sites, smokestacks, fires, power plants, and automobiles; the main sources of indoor PM include ambient PM, tobacco smoke, cooking, and heating appliances. PM causes lung inflammation and mucous secretion by acting on airway epithelial cells and alveolar macrophages and may lead to airway remodeling ${ }^{8}$.

Obstructive lung diseases, including chronic obstructive pulmonary disease (COPD) and asthma, are a large source of morbidity and mortality across the entire world ${ }^{9,10}$. Exposure to PM has been associated with worse morbidity and mortality in patients with COPD and asthma, including worse symptoms and quality of life and higher exacerbation rates and health care utilization ${ }^{11-17}$. Lung function is often used as an indicator of disease severity, and several studies have also focused on the impact of PM exposure on objective measures of lung function. This review will focus on the health effects of PM exposure on lung function in healthy children and adults, and in those with existing pulmonary disease.

\section{Impact of PM exposure in utero and during infancy}

Children may be particularly sensitive to the health effects of PM exposure, and early exposure during critical time points in lung development may lead to lasting impacts on lung function ${ }^{18-20}$. Several studies show that exposure to PM in utero is associated with decreased lung function in children, suggesting that fetal lung growth is impacted by maternal PM exposures ${ }^{21}$. For example, in a Californian study of 232 children with asthma, fetal exposure to ambient $\mathrm{PM}_{10}$ during the first trimester of pregnancy was associated with a lower peak expiratory flow (PEF) between the ages of 6 and $11^{22}$. In a study of 176 children of non-smoking mothers, Jedrychowski et al. measured maternal exposure to PM using a backpack worn for 48 hours and showed that children exposed to higher concentrations of $\mathrm{PM}_{2.5}$ in utero had an approximately $90 \mathrm{~mL}$ lower forced expiratory volume in 1 second $\left(\mathrm{FEV}_{1}\right)$ at 5 years of follow-up ${ }^{23}$. Exposure to higher concentrations of $\mathrm{PM}_{10}$ during the first year of life was associated with a $\mathrm{FEV}_{1}$ reduction of nearly $60 \mathrm{~mL}$ in Swedish children aged 8 years old, suggesting that exposures during infancy have lasting health effects years later ${ }^{24}$. Importantly, analysis of the same cohort at 16 years of age shows that children with exposure to higher concentrations of $\mathrm{PM}_{10}$ during the first year of life (above the median concentration) were more likely to have $\mathrm{FEV}_{1}$ and forced vital capacity (FVC) less than the lower limit of normal ${ }^{25}$. While these studies suggest in utero and infancy
PM exposure leads to lower lung function, others have not supported the relationship between early PM exposure and lung function decrements. In a German study of 2226 children, investigators used comprehensive land-use regression modeling to estimate yearly average PM concentrations at the time of each participant's birth. Early long-term PM exposure was not found to be associated with spirometric outcomes at 15 years of age ${ }^{26}$. In a Swiss study, maternal exposure to $\mathrm{PM}_{10}$ measured daily during pregnancy was not found to be associated with lung volumes in 241 healthy newborns ${ }^{27}$. To address the knowledge gaps that persist, large cohort studies with frequent comprehensive participant evaluations and individual-level PM exposure assessments are necessary to identify potential time points of increased susceptibility of the developing lung.

\section{Impact of PM exposure in healthy children}

The research evaluating the impact of PM exposure on lung function in healthy children is relatively scarce and inconsistent. Several observational studies demonstrate that PM exposure may have short- and long-term impacts on lung function in children without known lung disease. A longitudinal study by Castro et al. found that an increase in 2-day lagged PM was associated with a $0.34 \mathrm{~L} / \mathrm{min}$ decrease in PEF in 118 schoolchildren in Rio de Janeiro ${ }^{28}$. Similarly, an air pollution episode resulting in a 1-day $\mathrm{PM}_{10}$ concentration of $174 \mu \mathrm{g} / \mathrm{m}^{3}$ was associated with worse same-day spirometry in 112 healthy Dutch children ${ }^{29}$. Higher concentration of 8-hour $\mathrm{PM}$, measured on the morning prior to lung function testing, was associated with a marginal decrease in $\mathrm{FEV}_{1}$ and FVC in 163 healthy Austrian schoolchildren ${ }^{30}$. However, after accounting for nitrogen dioxide concentrations, this association was attenuated, highlighting the importance of identifying all exposures that may impact lung function.

The Children's Health Study followed respiratory growth over a period of 8 years in 1759 Californian children. Children exposed to the highest $\mathrm{PM}_{25}$ concentrations had an approximately $80 \mathrm{~mL}$ lower FEV than children exposed to the lowest level of $\mathrm{PM}^{19}$, an effect size similar to observed values in children exposed to maternal smoking ${ }^{19,31,32}$. In the same cohort, children living in residences closer to roadways, with higher estimated PM concentrations, had approximately $3 \%$ lower $\mathrm{FEV}_{13}{ }^{33}$, highlighting the contribution of traffic-related pollution to respiratory health. A study of 2307 healthy 10-year-old children in Norway found that an increase in the lifetime exposure to PM was associated with a $58-66 \mathrm{~mL} / \mathrm{sec}$ lower $\mathrm{PEF}^{34}$, and in 179 British schoolchildren followed for several months, higher PM was associated with a $4 \%$ increase in the odds of having a lower PEF (defined as greater than $20 \%$ below the median $)^{35}$.

There were no consistent associations between PM exposure and lung function in a 3-year longitudinal study of 1150 Austrian schoolchildren, including both healthy children and those with asthma $^{36}$. In an analysis of data from the Six Cities Study, indoor measurements of $\mathrm{PM}_{2.5}$ showed no direct association with pulmonary function measurements in a random sample of 2994 children $^{37}$. The discrepancy in research may be due to difficulty in performing lung function testing in children, or in part due to the nature of the exposure and unmeasured changes in PM concentration over 
time. Although there are few cohorts that extend from childhood to adulthood, these findings suggest that exposure in early life may have implications in the development of future airway disease and highlight the need for comprehensive longitudinal studies.

\section{Impact of PM exposure in children with asthma}

Children with existing lung disease are likely to be more susceptible to lung function changes following exposure to PM. In a study of 326 elementary schoolchildren in Seattle, 24 of whom had asthma, a $20 \mu \mathrm{g} / \mathrm{m}^{3}$ increase in ambient $\mathrm{PM}_{2.5}$ concentration measured over 2 years at the children's school was associated with a 34 and $37 \mathrm{~mL}$ drop in $\mathrm{FEV}_{1}$ and $\mathrm{FVC}$, respectively, in those with asthma ${ }^{38}$. British children with wheezing had increased odds of having a drop in PEF when exposed to higher concentrations of outdoor PM measured over the course of a winter season ${ }^{35}$. Exposure to higher PM concentrations over shorter time periods can lead to changes in lung function as well. When exposed to higher concentrations of ambient $\mathrm{PM}_{25}$ over a 3-day period, children with asthma in Canada were found to have a decrease in $\mathrm{FEV}_{1}$ and $\mathrm{FVC}^{39}$. An increase of $10 \mu \mathrm{g} / \mathrm{m}^{3}$ in 24-hour mean PM was associated with a drop of $3 \mathrm{~L} / \mathrm{min}$ in PEF in Japanese children hospitalized for severe asthma exacerbations ${ }^{40}$. Delfino et al. followed 53 children with asthma living in Los Angeles and found that an interquartile range (IQR) increase in 1-hour peak PM was associated with a $1.32 \%$ decrease in same-day percent predicted $\mathrm{FEV}_{1}{ }^{41}$. In a study of 19 children with asthma, Allen et al. found that a higher 24-hour concentration of $\mathrm{PM}_{25}$, measured over a period of 10 days, was associated with worse lung function as measured by daily PEF and $\mathrm{FEV}_{1}{ }^{42}$. Although less studied, short-term increases in indoor PM exposures have also been associated with lower lung function in children with asthma. A higher 24-hour indoor PM concentration measured over a period of 10 days was associated with a decrease in same-day and 1-day lagged PEF and $\mathrm{FEV}_{1}$ in Seattle children with asthma ${ }^{43}$. In another study, higher 24-hour indoor PM concentrations were associated with worse PEF in 22 children with asthma living in the United Kingdom ${ }^{44}$.

Studies examining the relationship between PM exposure and lung function in children with asthma have been inconsistent. In the Children's Health Study, there was no significant effect of PM exposure on lung function in the 483 children with a history of doctor-diagnosed asthma ${ }^{19}$. The authors suggest that the smaller sample size in this subgroup may have contributed to these findings. Noting the lack of consistency in quantitative outcomes, Weinmayr et al. completed a meta-analysis of 36 studies evaluating the association of PM and respiratory symptoms and PEF in children with asthma or asthma-like symptoms. Although there is clear evidence of worsening respiratory symptoms associated with higher PM concentrations, the authors report a non-significant decrease in PEF of $0.082 \mathrm{~L} / \mathrm{min}$ per unit increase in $\mathrm{PM}^{45}$. Furthermore, investigators have often noticed a disconnect between asthma symptoms and lung function ${ }^{46}$, suggesting that lung function changes may not be the most sensitive marker of disease burden in children.

\section{Impact of PM exposure on adults}

Although the developing lung may be more vulnerable to PM exposures, several studies show that adults are susceptible to air pollution exposures as well. The SAPALDIA study of nearly 10,000
Swiss adults showed that a $10 \mu \mathrm{g} / \mathrm{m}^{3}$ increase in $\mathrm{PM}_{10}$ was associated with a $3.4 \%$ decrease in FVC in a cross-sectional analysis, even after adjusting for cigarette use ${ }^{47,48}$. In the Normative Aging Study, 858 elderly men living in the Boston area were followed for a period of over 10 years, and exposure to ambient black carbon (a marker of traffic-related PM) was estimated using spatiotemporal land use regression models. Higher yearly black carbon concentration was associated with an increase in the normal age-related rate of decline of $\mathrm{FEV}_{1}$ and $\mathrm{FVC}^{49}$. Similarly, higher concentrations of previous-day ambient $\mathrm{PM}_{25}$ were associated with approximately $20 \mathrm{~mL}$ lower FEV , and FVC in nonsmoking adults in the Framingham Heart study ${ }^{50}$, and exposure to higher long-term concentrations of PM (yearly levels) was associated with lower FEV, and a faster rate of lung function decline ${ }^{51}$. In this cohort, followed for over 10 years, a $10 \mu \mathrm{g} / \mathrm{m}^{3}$ increase in $\mathrm{PM}_{2.5}$ was associated with an additional $10.5 \mathrm{~mL}$ annual decline in $\mathrm{FEV}_{1}$ beyond the normal age-related decline, suggesting that exposure to even moderate concentrations of PM can lead to meaningful lung function decline in healthy adults. Though the absolute changes in lung function in the above studies are of relatively low magnitude, prior research has shown that decreases in $\mathrm{FEV}_{1}$ are associated with all-cause mortality ${ }^{52,53}$ and that lower lung function is associated with higher rates of cardiovascular disease $e^{54,55}$.

\section{Adults with existing lung disease}

There are few studies investigating the effects of PM on lung function in adults with established lung disease, such as COPD and asthma. The studies that do exist suggest that among individuals with established COPD, long-term exposure to outdoor PM may be linked to lung function decline. For example, $\mathrm{PM}_{2.5}$ exposure was associated with $\mathrm{FEV}_{1}$ decline among 1218 subjects with severe COPD followed for an average of 29.2 months in the National Emphysema Treatment Trial (NETT) ${ }^{56}$. Similarly, among 401 individuals with COPD and $\alpha$-1-antitrypsin deficiency, a $10 \mu \mathrm{g} / \mathrm{m}^{3}$ increase in $\mathrm{PM}_{10}$ was associated with an additional $30 \mathrm{~mL} /$ year decline in $\mathrm{FEV}_{1}{ }^{57}$. Though these studies are suggestive, whether these findings extend to patients without $\alpha$-1-antitrypsin deficiency or severe emphysema is unclear. Long-term studies of air pollution on a diverse group of subjects with COPD, including those with heavy smoking exposure, are needed to further clarify the effects of air pollution on COPD progression.

Short-term variation in pollution may also be associated with changes in lung function in patients with chronic lung disease; however, studies investigating short-term variation in pollution and lung function in adults with COPD or asthma have been inconsistent and interpretations are limited by small sample sizes. For example, Peacock et al. recruited 94 COPD subjects who filled out daily diaries. An IQR increase in $\mathrm{PM}_{10}$ was linked to an approximately $13 \%$ increase in odds of symptomatic decreases in PEF, defined as a fall in PEF for at least 2 days plus a reported increase in dyspnea $^{11}$. In a recent Italian study, increased outdoor $\mathrm{PM}_{10}$ concentrations were associated with lower $\mathrm{FEV}_{1}$ and FVC in COPD patients presenting with urgent hospitalization ${ }^{58}$. Similarly, Lagorio et al. showed that increased ambient $\mathrm{PM}_{2.5}$ and $\mathrm{PM}_{10}$ concentrations were associated with lower lung function ( $\mathrm{FEV}_{1}$ and $\mathrm{FVC}$ ) in subjects with COPD, and the effect on FEV, appeared only when 72 hours of exposure were accumulated ${ }^{59}$. However, other studies 
have not shown a link between PM and short-term changes in lung function among those with COPD. A small panel study including 17 subjects with COPD showed no consistent association between PM with lung function over 12 days $^{60}$. A cohort of patients with COPD followed for 3 months found that an increase in $\mathrm{PM}_{10}$ was associated with an increase in nighttime symptoms, but there was no change in lung function ${ }^{61}$. Similarly, Hansel et al. identified that indoor PM is linked to respiratory symptoms and exacerbations, but not lung function, among former smokers with $\mathrm{COPD}^{15}$.

Studies that have investigated the short-term effects of PM on lung function in subjects with asthma have also been inconsistent. In a real-time exposure study of 60 adults with mild to moderate asthma, McCreanor et al. found that $\mathrm{FEV}_{1}$ decreased up to $6.1 \%$ following a 2-hour walk in a high-traffic area (with corresponding higher $\mathrm{PM}_{25}$ concentration) as compared to a walk in a park (with lower $\mathrm{PM}_{2.5}^{2.5}$ concentration) of similar duration ${ }^{62}$. In a longitudinal analysis, Park et al. found an increase in $\mathrm{PM}_{10}$ concentration was associated with increases in PEF variability of $>20 \%$ and a decrease in the mean PEF among 64 adults with asthma ${ }^{63}$. Balmes et al. noted that those with asthma with the middle and highest tertiles of ambient $\mathrm{PM}_{2.5}$ exposure had an increased risk of having $\mathrm{FEV}_{1}$ below the lower limit of normal (odds ratio $[\mathrm{OR}]=1.9395 \%$ confidence interval [CI]: 0.94, 3.95 and OR=2.23 95\% CI: $1.08,4.61)$, but only among females ${ }^{64}$. Using biweekly spirometry over 6 months on a group of 54 adult asthmatics, Penttinen et al. found that particle number concentrations on the preceding days were inversely, but mostly non-significantly, associated with $\mathrm{FEV}_{1}, \mathrm{FVC}$, and PEF, and no associations were observed with larger particles $\left(\mathrm{PM}_{10}\right)^{65}$. Several other studies showed no association between PM and lung function in adults with asthma. Though Lagorio et al. had observed a negative association between PM and lung function in subjects with COPD, there was no association between PM and lung function decrement among those with asthma ${ }^{59}$. Another study including subjects with COPD and asthma showed no association between indoor or outdoor air quality on lung function ${ }^{66}$. A study from Italy by Maestrelli et al. followed adult subjects with asthma periodically over 2 years and showed that measured personal exposure to $\mathrm{PM}_{10}$ during the 24 hours prior to assessment was associated with respiratory symptoms, but not $\mathrm{FEV}_{1}{ }^{67}$.

Given the relatively small size of studies of air pollution on shortterm changes in lung function in adults with COPD and asthma, they may not have been adequately powered to detect an association between pollutant exposure and lung function. Alternatively, it is possible that the adverse effects of PM exposure are linked to changes in smaller caliber airways that are not adequately captured by spirometric measures such as $\mathrm{FEV}_{1}$.

\section{Effect of PM reduction on lung function}

While the observational findings linking higher PM to worse lung function are intriguing, there is a need to provide additional levels of evidence, including assessment of temporality and observation as to whether lung function improves with reduction of PM exposure, to establish causality. Importantly, studies have shown that a decrease in pollution can improve lung function in both children and adults. For example, the Children's Health Study in southern
California followed three separate cohorts of children during periods of increasing PM regulation and therefore decreasing average $\mathrm{PM}$ concentrations. Investigators found higher FEV and FVC in the children exposed to the lowest concentrations of PM and, as air quality improved, the proportion of children with clinically low $\mathrm{FEV}_{1}$, subsequently declined ${ }^{68}$. Similarly, reductions in PM in an urban area of the Netherlands were associated with a $3 \%$ and $6 \%$ improvement in $\mathrm{FEV}_{1}$ and FVC, respectively, in both children and adults $^{69}$. In the SAPALDIA study, a $10 \mu \mathrm{g} / \mathrm{m}^{3}$ decrease in $\mathrm{PM}_{10}$ concentration was associated with a $9 \%$ decrease in the rate of yearly decline of $\mathrm{FEV}_{1}$ in over 9000 randomly selected Swiss adults ${ }^{70}$. These studies highlight that even modest reductions in PM can translate to meaningful improvements in lung function.

As the EPA does not regulate the indoor environment, interventions to mitigate exposure to indoor PM are less well studied. A small number of research studies have shown improvements in indoor PM concentrations following behavioral modifications and use of indoor air cleaners ${ }^{71-73}$. Most of these studies did not assess the impact of these modifications on lung function, and the results are inconsistent in the ones that do. In one study of 48 nonsmoking adults, air cleaners placed in the living room and bedroom decreased $\mathrm{PM}_{25}$ concentrations but did not improve lung function in these participants, although conclusions may be limited by the small sample size $^{74}$. In a randomized study of active versus sham air cleaners in 35 healthy college students in China, 48 hours of air purification significantly reduced indoor $\mathrm{PM}_{2.5}$ concentration by $57 \%$. This decrease was associated with a significant reduction in circulating inflammatory markers, along with a non-significant trend towards slight improvement in lung function following air purification ${ }^{75}$. Air cleaners that were run for 1 week in 20 homes on the First Nations reserve in Canada significantly decreased indoor $\mathrm{PM}_{2.5}$ concentrations, a reduction that was associated with a $217 \mathrm{~mL}$ increase in $\mathrm{FEV}_{1}$ in 37 healthy individuals living in the homes ${ }^{76}$. These studies highlight the potential for indoor air modification to reduce total PM exposure; whether the improvement in indoor air quality can lead to improvements in lung function is yet to be determined.

\section{Potential mechanisms of susceptibility to PM}

The precise mechanism as to how PM may influence health and lung function is unknown. Studies have suggested that PM may mediate adverse health effects via the generation of reactive oxygen species $^{77-79}$, activation of cell signaling pathways, and alterations of respiratory tract barrier function and antioxidant defenses, all of which may lead to airway inflammation and changes in pulmonary function ${ }^{80}$. Additionally, cellular changes resulting from PM exposure may cause epigenetic modifications, leading to alterations in gene expression ${ }^{81}$. For example, results from the ENVIRONAGE birth cohort showed that $\mathrm{PM}_{2.5}$ exposure during gestation was associated with placental mitochondrial DNA methylation in 381 mother-newborn pairs ${ }^{82}$. These studies may offer insight into how PM exposure in utero may impact lung function later in life. Furthermore, activation of many cellular signaling pathways has been attributed to specific chemical and metal constituents of PM that have been isolated in vitro. This suggests that PM of various sources may lead to diverse responses, making compositional analysis of $\mathrm{PM}$ by region an important consideration for future research ${ }^{81,83}$. 
Patient factors, including demographic and genetic factors, may modify the impact of PM exposures on lung function. Our review reinforces the conclusion that PM exposure can have important impacts on lung function in those with and without existing lung disease; however, whether individuals with pre-existing respiratory disease are more susceptible to the adverse effects of PM exposure is unclear. Few studies examine the variability in lung function response to PM exposure specifically by respiratory disease status. Toxicological studies suggest that the presence of allergic airway conditions may increase susceptibility to PM exposure; however, epidemiologic studies have been inconsistent in clarifying this relationship ${ }^{84}$. For example, in Koenig et al.'s study of Seattle schoolchildren, PM exposure impacted lung function in only those children with asthma, not healthy children ${ }^{38}$. Conversely, in a study of Mexico City schoolchildren, decrements in FVC following higher exposure to $\mathrm{PM}_{2.5}$ were seen in both the 158 asthmatic children and the 50 children without asthma ${ }^{85}$. Similarly, individuals with COPD may have impairment in mucociliary clearance, which may lead to an increase in dose of fine particles ${ }^{86}$ and resultant greater risk of PM-related respiratory effects, although epidemiological studies are needed to confirm this hypothesis ${ }^{84}$. Additionally, several studies have suggested that the impact of PM on lung function may vary by gender, and early life may be a critical time window when PM may adversely affect lung function. A few studies have also investigated whether genetic polymorphisms may modify the effects of PM on lung function. For example, results from Breton et al. suggest that genetic variations in the glutathione synthesis pathway may modify the impact of PM exposure on lung function in children ${ }^{87}$ and several investigations from the SAPALDIA cohort suggest that genetic variations potentially mediate the effect of PM on lung function decline ${ }^{88,89}$. Identifying risk factors of those who will be more susceptible to the health effects of PM exposure is a research priority.

\section{Conclusion}

In summary, the existing research suggests that PM exposure can influence lung development and have an important impact on lung function in both children and adults, and in those with and without existing lung disease. Although not without inconsistencies, this research adds to the wider body of literature that supports an association between PM exposure and worse respiratory symptoms. To address the knowledge gaps that persist, large cohort studies with frequent comprehensive participant evaluations and individuallevel PM exposure assessments are needed. In particular, studies on indoor air pollution have tended to be small, making definitive conclusions more challenging. In addition, size and composition of PM may have differing health effects; however, these differential effects have not yet been clearly elucidated. Lastly, there are several factors that may mediate the effects of PM exposure on lung health, such as timing of exposure, chronic lung diseases (including but not limited to obstructive airway diseases), genetics, and even other exposures such as medication use. Importantly, the studies to date suggest that relatively low concentrations of PM can negatively impact lung function, suggesting that meaningful health outcomes occur following exposure to relatively modest pollutant concentrations, many of which fall below the current EPA limits. Furthermore, while the observed decrements in lung function are relatively small, they have the potential to be clinically meaningful, especially in children, as those with lower lung function have been shown to have an increased risk of developing asthma ${ }^{90}$.

Moreover, the improvement in lung function seen following PM reduction implies that the majority of the population will benefit from continued regulation of PM levels. In addition, the importance of short-term exposures is reflected in EPA standards that regulate not only average annual PM concentration but also 24-hour concentrations. To reflect the growing body of evidence suggesting the adverse impact of short-term PM exposures, these standards were strengthened in $2006^{6}$. Policies and methods to decrease PM exposure are crucial to minimize the health impact of continued PM exposure on lung health. Due to the regulatory programs delineated as part of the original 1970 Clean Air Act and the 1990 amendments, there has been a $34 \%$ decrease in the annual national average of $\mathrm{PM}^{91}$. It is hoped that continued regulation of PM will help alleviate the impact that exposure has on the developing and adult lung.

\section{Competing interests}

The authors have no competing interests to disclose.

\section{Grant information}

LMP is supported by NIH grant K23ES025781, NNH is supported by NIH grants R01ES023500, R01ES018845, R01ES022607, P50MD010431, P01ES018176/ RD83451001, and P50ES015903.

\section{Acknowledgements}

The authors would like to thank Carrie Price of the Welch Medical Library for her assistance in searching the published literature on this topic.
1. Silva RA, West JJ, Zhang Y, et al:: Global premature mortality due to anthropogenic outdoor air pollution and the contribution of past climate change. Environ Res Lett. 2013; 8(3): 34005 Publisher Full Text

2. Lelieveld J, Evans JS, Fnais M, et al:: The contribution of outdoor air pollution sources to premature mortality on a global scale. Nature. 2015; 525(7569): $367-71$

PubMed Abstract | Publisher Full Text

3. World Health Organization: Burden of disease from household air pollution for
2012. WHO, Geneva, 2014

Reference Source

4. National Ambient Air Quality Standards for Ozone. Washington, DC. U.S. Environmental Protection Agency, 2011.

Reference Source

5. Anderson JO, Thundiyil JG, Stolbach A: Clearing the air: a review of the effects of particulate matter air pollution on human health. J Med Toxicol. 2012; 8(2): 166-75.

PubMed Abstract | Publisher Full Text | Free Full Text 
6. EPA US: Final Report: Integrated Science Assessment for Particulate Matter. Washington, DC: U.S. Environmental Protection Agency, 2009.

Reference Source

7. Laden F, Neas LM, Dockery DW, et al:: Association of fine particulate matter from different sources with daily mortality in six U.S. cities. Environ Health Perspect. 2000; 108(10): 941-7.

PubMed Abstract | Free Full Text

8. Churg A, Brauer M, del Carmen Avila-Casado M, et al.: Chronic exposure to high levels of particulate air pollution and small airway remodeling. Environ Health Perspect. 2003; 111(5): 714-8.

PubMed Abstract | Free Full Text

9. Global Strategy for the Diagnosis, Management and Prevention of COPD, Global Initiative for Chronic Obstructive Lung Disease (GOLD). 2015. Reference Source

10. National Heart Lung, and Blood Institute: National Asthma Education and Prevention Program: Expert Panel Report 3: Guidelines for the Diagnosis and Management of Asthma. 2007. Reference Source

11. Peacock JL, Anderson HR, Bremner SA, et al.: Outdoor air pollution and respiratory health in patients with COPD. Thorax. 2011; 66(7): 591-6. PubMed Abstract | Publisher Full Text

12. Dominici F, Peng RD, Bell ML, et al.: Fine particulate air pollution and hospital admission for cardiovascular and respiratory diseases. JAMA. 2006; 295(10): 1127-34.

PubMed Abstract | Publisher Full Text | Free Full Text

13. Breysse $\mathrm{PN}$, Diette GB, Matsui EC, et al.: Indoor air pollution and asthma in children. Proc Am Thorac Soc. 2010; 7(2): 102-6.

PubMed Abstract | Publisher Full Text | Free Full Text

14. Diette GB, Hansel NN, Buckley TJ, et al:: Home indoor pollutant exposures among inner-city children with and without asthma. Environ Health Perspect. 2007; 115(11): 1665-9.

PubMed Abstract | Free Full Text

15. Hansel NN, McCormack MC, Belli AJ, et al:: In-home air pollution is linked to respiratory morbidity in former smokers with chronic obstructive pulmonary disease. Am J Respir Crit Care Med. 2013; 187(10): 1085-90. PubMed Abstract | Publisher Full Text | Free Full Text

16. McCormack MC, Breysse PN, Matsui EC, et al:: In-home particle concentrations and childhood asthma morbidity. Environ Health Perspect. 2009; 117(2): 294-8. PubMed Abstract | Publisher Full Text | Free Full Text

17. Li S, Williams G, Jalaludin B, et al:: Panel studies of air pollution on children's lung function and respiratory symptoms: a literature review. J Asthma. 2012; 49(9): 895-910.

PubMed Abstract | Publisher Full Text

18. Dietert RR, Etzel RA, Chen D, et al:: Workshop to identify critical windows of exposure for children's health: immune and respiratory systems work group summary. Environ Health Perspect. 2000; 108(Suppl 3): 483-90. PubMed Abstract | Free Full Text

19. Gauderman WJ, Avol E, Gilliland F, et al:: The effect of air pollution on lung development from 10 to 18 years of age. N Engl J Med. 2004; 351(11): 1057-67. PubMed Abstract | Publisher Full Text

20. Nordling E, Berglind N, Melén E, et al.: Traffic-related air pollution and childhood respiratory symptoms, function and allergies. Epidemiology. 2008; 19(3): 401-8. PubMed Abstract | Publisher Full Tex

21. Mölter A, Agius RM, de Vocht $F$, et al.: Long-term exposure to $\mathrm{PM}_{10}$ and $\mathrm{NO}_{2}$ in association with lung volume and airway resistance in the MAAS birth cohort. Environ Health Perspect. 2013; 121(10): 1232-8.

PubMed Abstract | Publisher Full Text | Free Full Text

22. F Mortimer K, Neugebauer R, Lurmann F, et al:: Air pollution and pulmonary function in asthmatic children: effects of prenatal and lifetime exposures. Epidemiology. 2008; 19(4): 550-7; discussion 561-2. PubMed Abstract | Publisher Full Text | F1000 Recommendation

23. F Jedrychowski WA, Perera FP, Maugeri U, et al.: Effect of prenatal exposure to fine particulate matter on ventilatory lung function of preschool children of non-smoking mothers. Paediatr Perinat Epidemiol. 2010; 24(5): 492-501. PubMed Abstract | Publisher Full Text | Free Full Text | F1000 Recommendation

24. F Schultz ES, Gruzieva O, Bellander T, et al.: Traffic-related air pollution and lung function in children at 8 years of age: a birth cohort study. Am J Respir Crit Care Med. 2012; 186(12): 1286-91.

PubMed Abstract | Publisher Full Text | F1000 Recommendation

25. F Schultz ES, Hallberg J, Bellander T, et al.: Early-Life Exposure to Traffic-related Air Pollution and Lung Function in Adolescence. Am J Respir Crit Care Med. 2016; 193(2): 171-7.

PubMed Abstract | Publisher Full Text | F1000 Recommendation

26. F Fuertes $\mathrm{E}$, Bracher J, Flexeder $\mathrm{C}$, et al:: Long-term air pollution exposure and lung function in $\mathbf{1 5}$ year-old adolescents living in an urban and rural area in Germany: The GINIplus and LISAplus cohorts. Int J Hyg Environ Health. 2015; 218(7): 656-65.

PubMed Abstract | Publisher Full Text | F1000 Recommendation

27. $\mathrm{F}$ Latzin $\mathrm{P}$, Röösli $\mathrm{M}$, Huss $\mathrm{A}$, et al.: Air pollution during pregnancy and lung function in newborns: a birth cohort study. Eur Respir J. 2009; 33(3): 594-603. PubMed Abstract | Publisher Full Text | F1000 Recommendation

28. F Castro HA, Cunha MF, Mendonça GA, et al.: Effect of air pollution on lung function in schoolchildren in Rio de Janeiro, Brazil. Rev Saude Publica. 2009; 43(1): 26-34.

PubMed Abstract | Publisher Full Text | F1000 Recommendation

29. Brunekreef B, Hoek G: The relationship between low-level air pollution exposure and short-term changes in lung function in Dutch children. $J$ Expo Anal Environ Epidemiol. 1993; 3(Suppl 1): 117-28.

PubMed Abstract

30. F Moshammer $\mathrm{H}$, Hutter HP, Hauck $\mathrm{H}$, et al.: Low levels of air pollution induce changes of lung function in a panel of schoolchildren. Eur Respir J. 2006; 27(6) 1138-43.

PubMed Abstract | Publisher Full Text | F1000 Recommendation

31. Tager IB, Weiss ST, Muñoz A, et al:: Longitudinal study of the effects of maternal smoking on pulmonary function in children. N Engl J Med. 1983; 309(12): 699-703. PubMed Abstract | Publisher Full Text

32. Wang X, Wypij D, Gold DR, et al:: A longitudinal study of the effects of parental smoking on pulmonary function in children 6-18 years. Am J Respir Crit Care Med. 1994; 149(6): 1420-5

PubMed Abstract | Publisher Full Tex

33. F Urman R, McConnell R, Islam T, et al:: Associations of children's lung function with ambient air pollution: joint effects of regional and near-roadway pollutants. Thorax. 2014; 69(6): 540-7.

PubMed Abstract | Publisher Full Text | Free Full Text | F1000 Recommendation

34. F Oftedal B, Brunekreef B, Nystad W, et al:: Residential outdoor air pollution and lung function in schoolchildren. Epidemiology. 2008; 19(1): 129-37. PubMed Abstract | Publisher Full Text | F1000 Recommendation

35. F Peacock JL, Symonds $\mathrm{P}$, Jackson $\mathrm{P}$, et al:: Acute effects of winter air pollution on respiratory function in schoolchildren in southern England. Occup Environ Med. 2003; 60(2): 82-9.

PubMed Abstract | Publisher Full Text | Free Full Text | F1000 Recommendation

36. Frischer $\mathrm{T}$, Studnicka $\mathrm{M}$, Gartner $\mathrm{C}$, et al.: Lung function growth and ambient ozone: a three-year population study in school children. Am J Respir Crit Care Med. 1999; 160(2): 390-6.

PubMed Abstract | Publisher Full Text

37. Neas LM, Dockery DW, Ware JH, et al.: Concentration of indoor particulate matter as a determinant of respiratory health in children. Am J Epidemiol. 1994; 139(11): 1088-99.

PubMed Abstract

38. Koenig JQ, Larson TV, Hanley QS, et al.: Pulmonary function changes in children associated with fine particulate matter. Environ Res. 1993; 63(1): 26-38. PubMed Abstract | Publisher Full Text

39. F Liu L, Poon R, Chen L, et al:: Acute effects of air pollution on pulmonary unction, airway inflammation, and oxidative stress in asthmatic children. Environ Health Perspect. 2009; 117(4): 668-74.

PubMed Abstract | Publisher Full Text | Free Full Text | F1000 Recommendation

40. F Yamazaki S, Shima M, Ando M, et al.: Effect of hourly concentration of particulate matter on peak expiratory flow in hospitalized children: a panel study. Environ Health. 2011; 10: 15.

PubMed Abstract | Publisher Full Text | Free Full Text | F1000 Recommendation

41. Delfino RJ, Staimer N, Tjoa T, et al:: Personal and ambient air pollution exposures and lung function decrements in children with asthma. Environ Health Perspect. 2008; 116(4): 550-8.

PubMed Abstract | Free Full Text

42. Allen RW, Mar T, Koenig J, et al.: Changes in lung function and airway inflammation among asthmatic children residing in a woodsmoke-impacted urban area. Inhal Toxicol. 2008; 20(4): 423-33.

PubMed Abstract | Publisher Full Text

43. F Trenga CA, Sullivan JH, Schildcrout JS, et al.: Effect of particulate air pollution on lung function in adult and pediatric subjects in a Seattle pane study. Chest. 2006; 129(6): 1614-22.

PubMed Abstract | Publisher Full Text | F1000 Recommendation

44. Woods KE, Apsley A, Semple S, et al.: Domestic airborne fine particulate matter exposure and asthma control among children receiving inhaled steroid treatment. Indoor Built Environ. 2014; 23(3): 497-503. Publisher Full Text

45. F Weinmayr G, Romeo E, De Sario M, et al.: Short-term effects of PM and $\mathrm{NO}_{2}$ on respiratory health among children with asthma or asthma-like symptoms: a systematic review and meta-analysis. Environ Health Perspect 2010; 118(4): 449-57.

PubMed Abstract | Publisher Full Text | Free Full Text | F1000 Recommendation

46. Bacharier LB, Strunk RC, Mauger D, et al:: Classifying asthma severity in children: mismatch between symptoms, medication use, and lung function. Am J Respir Crit Care Med. 2004; 170(4): 426-32.

PubMed Abstract | Publisher Full Text

47. Künzli N, Ackermann-Liebrich U, Brändli O, et al.: Clinically "small" effects of ai pollution on FVC have a large public health impact. Swiss Study on Air Pollution and Lung Disease in Adults (SAPALDIA) - team. Eur Respir J. 2000; 15(1): 131-6. PubMed Abstract | Publisher Full Text

48. Ackermann-Liebrich $\mathrm{U}$, Leuenberger $\mathrm{P}$, Schwartz $\mathrm{J}$, et al:: Lung function and long term exposure to air pollutants in Switzerland. Study on Air Pollution and Lung Diseases in Adults (SAPALDIA) Team. Am J Respir Crit Care Med. 1997; 155(1): 122-9.

PubMed Abstract | Publisher Full Tex 
49. F Lepeule J, Litonjua AA, Coull B, et al:: Long-term effects of traffic particles on lung function decline in the elderly. Am J Respir Crit Care Med. 2014; 190(5) $542-8$.

PubMed Abstract | Publisher Full Text | Free Full Text | F1000 Recommendation

50. Rice MB, Ljungman PL, Wilker EH, et al.: Short-term exposure to air pollution and lung function in the Framingham Heart Study. Am J Respir Crit Care Med. 2013; 188(11): 1351-7.

PubMed Abstract | Publisher Full Text | Free Full Text

51. Rice MB, Ljungman PL, Wilker EH, et al.: Long-term exposure to traffic emissions and fine particulate matter and lung function decline in the Framingham heart study. Am J Respir Crit Care Med. 2015; 191(6): 656-64. PubMed Abstract | Publisher Full Text | Free Full Text

52. Schünemann HJ, Dorn J, Grant BJ, et al.: Pulmonary function is a long-term predictor of mortality in the general population: 29-year follow-up of the Buffalo Health Study. Chest. 2000; 118(3): 656-64. PubMed Abstract | Publisher Full Text

53. Miller MR, Pedersen OF, Lange $P$, et al.: Improved survival prediction from lung function data in a large population sample. Respir Med. 2009; 103(3): 442-8. PubMed Abstract | Publisher Full Tex

54. Georgiopoulou VV, Kalogeropoulos AP, Psaty BM, et al.: Lung function and risk for heart failure among older adults: the Health ABC Study. Am J Med. 2011; 124(4): 334-41.

PubMed Abstract | Publisher Full Text | Free Full Text

55. Sin DD, Wu L, Man SF: The relationship between reduced lung function and cardiovascular mortality: a population-based study and a systematic review of the literature. Chest. 2005; 127(6): 1952-9.

PubMed Abstract | Publisher Full Text

56. F Kariisa M, Foraker R, Pennell M, et al:: Short- and long-term effects of ambient ozone and fine particulate matter on the respiratory health of chronic obstructive pulmonary disease subjects. Arch Environ Occup Health. 2015; 70(1): 56-62. PubMed Abstract | Publisher Full Text | F1000 Recommendation

57. F Wood AM, Harrison RM, Semple S, et al:: Outdoor air pollution is associated with rapid decline of lung function in alpha-1-antitrypsin deficiency. Occup Environ Med. 2010; 67(8): 556-61.

PubMed Abstract | Publisher Full Text | F1000 Recommendation

58. Mariani E, Bonati E, Veronesi L, et al:: Respiratory function in subjects with chronic obstructive pulmonary disease (COPD) and atmospheric pollution in the city of Parma. Preliminary analysis. Acta Biomed. 2010; 81(2): 109-14. PubMed Abstract

59. Lagorio S, Forastiere F, Pistelli R, et al:: Air pollution and lung function among susceptible adult subjects: a panel study. Environ Health. 2006; 5: 11. PubMed Abstract | Publisher Full Text | Free Full Text

60. Hsu SO, Ito K, Lippmann M: Effects of thoracic and fine PM and thei components on heart rate and pulmonary function in COPD patients. $J$ Expo Sci Environ Epidemiol. 2011; 21(5): 464-72.

PubMed Abstract | Publisher Full Text

61. Harré ES, Price PD, Ayrey RB, et al.: Respiratory effects of air pollution in chronic obstructive pulmonary disease: a three month prospective study. Thorax. 1997; 52(12): 1040-4.

PubMed Abstract | Publisher Full Text | Free Full Text

62. F McCreanor J, Cullinan P, Nieuwenhuijsen MJ, et al:: Respiratory effects of exposure to diesel traffic in persons with asthma. N Engl J Med. 2007; 357(23) 2348-58.

PubMed Abstract | Publisher Full Text | F1000 Recommendation

63. F Park JW, Lim YH, Kyung SY, et al:: Effects of ambient particulate matter on peak expiratory flow rates and respiratory symptoms of asthmatics during Asian dust periods in Korea. Respirology. 2005. 10(4): 470-6. PubMed Abstract | Publisher Full Text | F1000 Recommendation

64. F Balmes JR, Cisternas M, Quinlan PJ, et al.: Annual average ambient particulate matter exposure estimates, measured home particulate matter, and hair nicotine are associated with respiratory outcomes in adults with asthma. Environ Res. 2014; 129: 1-10.

PubMed Abstract | Publisher Full Text | Free Full Text | F1000 Recommendation

65. F Penttinen $\mathrm{P}$, Timonen KL, Tiittanen $\mathrm{P}$, et al:: Number concentration and size of particles in urban air: effects on spirometric lung function in adult asthmatic subjects. Environ Health Perspect. 2001; 109(4): 319-23. PubMed Abstract | Free Full Text | F1000 Recommendation

66. de Hartog JJ, Ayres JG, Karakatsani A, et al.: Lung function and indicators of exposure to indoor and outdoor particulate matter among asthma and COPD patients. Occup Environ Med. 2010; 67(1): 2-10. PubMed Abstract | Publisher Full Text

67. F Maestrelli P, Canova C, Scapellato ML, et al:: Personal exposure to particulate matter is associated with worse health perception in adult asthma. J Investig Allergol Clin Immunol. 2011; 21(2): 120-8.

PubMed Abstract | F1000 Recommendation

68. F Gauderman WJ, Urman R, Avol E, et al:: Association of improved air quality with lung development in children. N Engl J Med. 2015; 372(10): 905-13. PubMed Abstract | Publisher Full Text | Free Full Text | F1000 Recommendation

69. F Boogaard H, Fischer PH, Janssen NA, et al:: Respiratory effects of a reduction in outdoor air pollution concentrations. Epidemiology. 2013; 24(5): 753-61. PubMed Abstract | Publisher Full Text | F1000 Recommendation

70. F Downs $\mathrm{SH}$, Schindler C, Liu LJ, et al:: Reduced exposure to $\mathbf{P M}_{10}$ and attenuated age-related decline in lung function. N Engl J Med. 2007; 357(23): 2338-47. PubMed Abstract | Publisher Full Text | F1000 Recommendation

71. Butz $A M$, Matsui EC, Breysse $P$, et al:: A randomized trial of air cleaners and a health coach to improve indoor air quality for inner-city children with asthma and secondhand smoke exposure. Arch Pediatr Adolesc Med. 2011; 165(8): 741-8. PubMed Abstract | Publisher Full Text

72. Lanphear BP, Hornung RW, Khoury J, et al:: Effects of HEPA air cleaners on unscheduled asthma visits and asthma symptoms for children exposed to secondhand tobacco smoke. Pediatrics. 2011; 127(1): 93-101. PubMed Abstract | Publisher Full Text | Free Full Text

73. Sublett JL: Effectiveness of air filters and air cleaners in allergic respiratory diseases: a review of the recent literature. Curr Allergy Asthma Rep. 2011; 11(5): 395-402.

PubMed Abstract | Publisher Full Text | Free Full Text

74. F Karottki DG, Spilak M, Frederiksen M, et al:: An indoor air filtration study in homes of elderly: cardiovascular and respiratory effects of exposure to particulate matter. Environ Health. 2013; 12: 116.

PubMed Abstract | Publisher Full Text | Free Full Text | F1000 Recommendation

75. F Chen $\mathrm{R}$, Zhao A, Chen $\mathrm{H}$, et al.: Cardiopulmonary benefits of reducing indoor particles of outdoor origin: a randomized, double-blind crossover tria of air purifiers. J Am Coll Cardiol. 2015; 65(21): 2279-87. PubMed Abstract | Publisher Full Text | F1000 Recommendation

76. F Weichenthal S, Mallach G, Kulka R, et al:: A randomized double-blind crossover study of indoor air filtration and acute changes in cardiorespiratory health in a First Nations community. Indoor Air. 2013; 23(3): 175-84. PubMed Abstract | Publisher Full Text | F1000 Recommendation

77. Kelly FJ, Fussell JC: Size, source and chemical composition as determinants of toxicity attributable to ambient particulate matter. Atmos Environ. 2012; 60: 504-26.

Publisher Full Text

78. Hogervorst JG, de Kok TM, Briedé JJ, et al:: Relationship between radical generation by urban ambient particulate matter and pulmonary function of school children. J Toxicol Environ Health A. 2006; 69(3-4): 245-62. PubMed Abstract | Publisher Full Text

79. Janssen NA, Strak M, Yang A, et al.: Associations between three specific a-cellular measures of the oxidative potential of particulate matter and markers of acute airway and nasal inflammation in healthy volunteers. Occup Environ Med. 2015; 72(1): 49-56.

PubMed Abstract | Publisher Full Text

80. U.S. Environmental Protection Agency, Washington DC: Integrated science assessment for particulate matter. US Environmental Protection Agency Washington, DC. 2009.

Reference Source

81. Ji H, Khurana Hershey GK: Genetic and epigenetic influence on the response to environmental particulate matter. J Allergy Clin Immunol. 2012; 129(1): 33-41. PubMed Abstract | Publisher Full Text | Free Full Text

82. F Janssen BG, Byun HM, Gyselaers W, et al.: Placental mitochondrial methylation and exposure to airborne particulate matter in the early life environment: An ENVIRONAGE birth cohort study. Epigenetics. 2015; 10(6): 536-44. PubMed Abstract | Publisher Full Text | Free Full Text | F1000 Recommendation

83. Wu S, Deng F, Wei $\mathrm{H}$, et al:: Association of cardiopulmonary health effects with source-appointed ambient fine particulate in Beijing, China: a combined analysis from the Healthy Volunteer Natural Relocation (HVNR) study. Environ Sci Technol. 2014; 48(6): 3438-48.

PubMed Abstract | Publisher Full Text

84. Sacks JD, Stanek LW, Luben TJ, et al.: Particulate matter-induced health effects: who is susceptible? Environ Health Perspect. 2011; 119(4): 446-54. PubMed Abstract | Publisher Full Text | Free Full Text

85. Barraza-Villarreal A, Sunyer J, Hernandez-Cadena L, et al:: Air pollution, airway inflammation, and lung function in a cohort study of Mexico City schoolchildren. Environ Health Perspect. 2008; 116(6): 832-8. PubMed Abstract | Free Full Text

86. Bennett WD, Zeman KL, Kim C, et al:: Enhanced deposition of fine particles in copd patients spontaneously breathing at rest. Inhal Toxicol. 1997; 9(1): 1-14. Publisher Full Text

87. $\mathrm{F}$ Breton $\mathrm{CV}$, Salam MT, Vora $\mathrm{H}$, et al.: Genetic variation in the glutathione synthesis pathway, air pollution, and children's lung function growth. $A m \mathrm{~J}$ Respir Crit Care Med. 2011; 183(2): 243-8.

PubMed Abstract | Publisher Full Text | Free Full Text | F1000 Recommendation

88. Curjuric I, Imboden M, Nadif R, et al: Different genes interact with particulate matter and tobacco smoke exposure in affecting lung function decline in the general population. PLoS One. 2012; 7(7): e40175

PubMed Abstract | Publisher Full Text | Free Full Tex

89. Imboden M, Schwartz J, Schindler C, et al:: Decreased PM exposure attenuates age-related lung function decline: genetic variants in p53, p21, and CCND1 modify this effect. Environ Health Perspect. 2009; 117(9): 1420-7. PubMed Abstract | Publisher Full Text | Free Full Text

90. Islam T, Gauderman WJ, Berhane K, et al:: Relationship between air pollution, lung function and asthma in adolescents. Thorax. 2007; 62(11): 957-63. PubMed Abstract | Publisher Full Text | Free Full Text

91. Office of Air and Radation, U.S. Enivronmnetal Protection Agency, Washington DC: The Benefits and Costs of the Clean Air Act from 1990 to 2020: Summary Report 2011

Reference Source 


\section{Open Peer Review}

\section{Current Peer Review Status:}

\section{Editorial Note on the Review Process}

Faculty Reviews are review articles written by the prestigious Members of Faculty Opinions. The articles are commissioned and peer reviewed before publication to ensure that the final, published version is comprehensive and accessible. The reviewers who approved the final version are listed with their names and affiliations.

\section{The reviewers who approved this article are:}

\section{Version 1}

\section{Xinbiao Guo}

Department of Occupational and Environmental Health Sciences, Peking University School of Public Health, Beijing, China

Competing Interests: No competing interests were disclosed.

\section{Stephan F van Eeden}

1 The Centre for Heart Lung Innovation, St Paul's Hospital, University of British Columbia, Vancouver, British Columbia, Canada

2 Division of Respirology, Department of Medicine, University of British Columbia, Vancouver, British Columbia, Canada

Competing Interests: No competing interests were disclosed.

\section{Alfésio Luís Ferreira Braga}

${ }^{1}$ Laboratory of Experimental Air Pollution (LPAE), University of Sao Paulo Medical School, Sao Paulo, Brazil

2 Catholic University of Santos, Santos, Brazil

Competing Interests: No competing interests were disclosed. 
The benefits of publishing with F1000Research:

- Your article is published within days, with no editorial bias

- You can publish traditional articles, null/negative results, case reports, data notes and more

- The peer review process is transparent and collaborative

- Your article is indexed in PubMed after passing peer review

- Dedicated customer support at every stage

For pre-submission enquiries, contact research@f1000.com 